\title{
Sociodemographic predictors of tobacco smoking among expatriate and national adolescents in the United Arab Emirates
}

Ayesha Siddiqua ${ }^{1}$, Rania Dghaim² ${ }^{2}$ and Caroline Barakat-Haddad ${ }^{3}$

${ }^{1}$ Department of Health Research Methods, Evidence, and Impact, McMaster University, Hamilton, Canada (Correspondence to: A. Siddiqua: ayesha. summer@gmail.com). ${ }^{2}$ Department of Natural Science and Public Health, College of Sustainability Sciences and Humanities, Zayed University, Dubai, United Arab Emirates. ${ }^{3}$ Faculty of Health Sciences, University of Ontario Institute of Technology, Oshawa, Canada.

\begin{abstract}
Background: Tobacco use among adolescents is an important public health concern as it causes various forms of smokingrelated health problems and can create a gateway for other substance abuse.

Aim: This study examined the prevalence, profile and predictors of tobacco use among expatriate and national adolescents living in the United Arab Emirates (UAE).

Methods: Using a cross-sectional study design (2007-2009), we collected data on the prevalence of tobacco use in 6363 adolescents aged 13-20 years, including current smokers of cigarettes, midwakh, shisha and any other form of tobacco. We also collected demographic, socioeconomic, residential and behavioural data.

Results: In the previous 30 days, 505 (8.9\%) participants had smoked cigarettes, $355(6.3 \%)$ had smoked midwakh, $421(7.4 \%)$ had smoked shisha and $380(6.4 \%)$ had smoked any other form of tobacco. Overall, 818 (14.0\%) adolescents were current smokers, who reported occasional or daily use of at least one form of tobacco in the past 30 days. Results consistently indicated that the prevalence of tobacco use was higher among men than women, regardless of age and tobacco form. Among men, cigarette smoking was the most popular, whereas shisha was the most smoked form of tobacco among women. Being male and ever having used illegal drugs consistently emerged as significant predictors of all forms of tobacco use.
\end{abstract}

Conclusion: There is a need for continued public health strategies and education campaigns to discourage adolescents in the UAE from using tobacco.

Key words: Adolescents, Tobacco-use, Smoking, Gender differences, United Arab Emirates

Citation: Siddiqua A; Dghaim R; Barakat-Haddad C. Sociodemographic predictors of tobacco smoking among expatriate and national adolescents in the United Arab Emirates. East Mediterr Health J. 2018;24(3):283-294. https://doi.org/10.26719/2018.24.3.283

Received: 10/11/15; accepted: 19/02/17

Copyright @ World Health Organization (WHO) 2018. Some rights reserved. This work is available under the CC BY-NC-SA 3.0 IGO license (https:// creativecommons.org/licenses/by-nc-sa/3.o/igo).

\section{Introduction}

Recent research suggests worldwide estimates of $>150$ million adolescents who use tobacco (1). Tobacco use among adolescents is an important public health concern as it causes various forms of smoking-related health problems and can create a gateway for other substance abuse (2). The younger an individual starts smoking, the more difficult it is for them to quit later in life (3). Negative health consequences of smoking are a function of the duration (number of years smoking) and intensity (number of cigarettes smoked) of use (4). Thus, there is an increased risk of smoking-related health problems among individuals who begin smoking during adolescence.

In the United Arab Emirates (UAE), tobacco consumption has increased drastically in recent years as the number of cigarette factories has increased, and rapid economic and social changes have led to an increase in the popularity of tobacco $(5,6)$. Despite acknowledgement by the UAE Ministry of Health that tobacco use is a growing problem among adolescents (7), few studies have focused on this public health issue (8-10). In 2002, the UAE participated in the Global Youth Tobacco Survey (GYTS) that focused on adolescents aged 13-15 years (11). The survey showed that $20.9 \%$ of participants had ever smoked cigarettes and 21.9\% were current users of any form of tobacco. Overall, $29.7 \%$ of men and $12.6 \%$ of women were current users of any form of tobacco. A repeat of the GYTS in 2005 indicated that these numbers remained high, with $22.6 \%$ of participants reporting having ever smoked cigarettes and 19.5\% reporting current use of any form of tobacco $-25.2 \%$ for men versus $13.2 \%$ for women.

Identification of the profile and potential predictors of tobacco use among adolescents in the UAE is crucial for delivering effective tobacco control measures and health policies. Thus, the present study used the socioecological model of health to: (1) determine the prevalence of tobacco use; (2) examine the profile of tobacco use; and (3) assess demographic, socioeconomic, residential and behavioural predictors of tobacco use among the UAE adolescent population.

\section{Methods}

\section{Data source and study design}

This study utilized data from the National Study of Population Health in the UAE (2007-2009) research programme that was undertaken in collaboration with the UAE Ministry of Education. A cross-sectional survey 
was developed and administered to 6363 adolescents aged 13-20 years, who attended public and private schools in the 7 Emirates of the Federation. The developed survey consisted of 2 main components: (1) data on smoking behaviour, type and frequency of tobacco use; data related to other determinants of health; and demographic and socioeconomic data (12); and (2) data related to residential mobility and location, and residential characteristics.

\section{Sampling procedure}

A stratified sampling strategy based on school enrolment data from the UAE Ministry of Education identified the need to select 147 private and public schools from 10 educational zones. Schools were selected randomly by lottery using an updated (2005-2006) list of schools provided by the Ministry of Education. For schools that had $>1$ class per grade level, the fishbowl lottery method was used to select 1 class from each of Grades 10-12 from each selected school.

\section{Ethics and administration}

Ethical approval was obtained from the UAE Ministry of Education and Ministry of Health. Detailed information letters were sent to the parents or guardians of the participants 2 days prior to survey administration. These letters outlined the research objectives and methodology and requested participants' consent. Social workers were trained to administer the ist component of the survey to participants from the 3 selected classes from each school, during a spare period, in a classroom setting. The 2nd component was sent home with the participant in order to seek parental assistance with completion.

\section{Outcome variables}

Outcome variables were based on responses to 5 items from the questionnaire. One item asked participants if they had ever smoked cigarettes or any form of tobacco such as shisha (water pipe) or midwakh (dokha, small tobacco pipe) (yes/no/do not know). In a series of 4 items, and in relation to the past 30 days, participants were also asked the following questions. How often did you smoke cigarettes? How often did you smoke midwakh? How often did you smoke shisha? How often did you smoke any other form of tobacco? Participants were provided the following choices: daily/occasionally, in which case they were asked to circle the number of days between 1 and 30; not at all/do not know. In addition, 2 variables were derived. The 1st variable categorized participants as current smokers if they reported occasional or daily use of $\geq 1$ form of tobacco in the past 30 days (namely cigarettes, shisha, midwakh or other). This categorization is consistent with World Health Organization guidelines (13). The 2nd variable was derived to identify participants who reported occasional or daily use of $>1$ tobacco form (including combinations of any 2 of the following: cigarettes, shisha, midwakh, or other form) in the past 30 days.

\section{Explanatory variables}

Data related to the participants' demographic profiles included sex, age, type of school attended, whether the participant was exposed to tobacco smoke at home or with friends, whether the participant was born in the UAE, parental marital status, and parental education level. Nationality was grouped on the basis of similar cultures, traditions, ancestral linkages or geographical origins: UAE (local), GCC [included participants from GCC (Gulf Cooperation Council) countries or Greater Arab Free Trade Area], Arab/Middle East, Arab/Africa, South East Asia, Western, no nationality, and others.

For socioeconomic profile, data on participants' monthly family income included the following categories: $\leq 2000,2001-5000,5001-8000,8001-10$ 000, 10 001-12 000, 12 001-15 000, 15 001-20 000 and > 20000 UAE dirha. Data related to participants' residential profiles included location of residence, number of individuals who resided in the household, number of bedrooms in the residence, and number of previous residences. A residential crowding variable was calculated using the ratio for the number of individuals who resided in the household over the number of bedrooms in the residence.

Items related to behavioural lifestyle asked participants if they had ever used illegal drugs such as marijuana, hashish or cocaine (yes/no/do not know). In relation to unconventional drug use, participants were asked whether they had ever purposely inhaled gasoline fumes, glue, correction fluid, car exhaust or burning Black Ants (yes/no/do not know). These other forms of substance abuse are common knowledge among the UAE adolescent population and have been included in the UAE national health surveys. Recent United States Food and Drug Administration laboratory analysis has confirmed that Black Ants contain sildenafil, which is a current ingredient used for sexual enhancement products (14).

\section{Data analysis}

Data were analysed using SPSS version 20. Descriptive statistics were calculated for outcome and explanatory variables. To create binary outcome variables based on the 4 items regarding different forms of tobacco use, responses were categorized as daily/occasionally versus not at all. The $\chi^{2}$ test was used for bivariate analysis. All independent variables that were significant in the bivariate analysis were entered into logistic regression models to predict tobacco-use outcomes. Six logistic regression models were developed for smoking cigarettes, midwakh, shisha, other tobacco forms, current smoking, and smoking $>1$ form of tobacco. For each of the modelled outcomes, forward stepwise entry of variables was conducted using $P \leq 0.05$. For the independent variables, 1 category was chosen to be the reference category, with each category of the variable then compared to the reference.

\section{Results}

Overall, 52 public and 44 private schools participated in the study. Response rate ranged from 9\% (2 private schools in Dubai) to $100 \%$ (5 public schools in Fujairah and 5 private and 3 public schools in Western Region), resulting in an overall response rate of 65\% (4115 responses) (see 12 for 
details regarding response rate from public and private schools in each emirate). Overall, 3101 (49\%) participants were of local national origin and 2785 (44\%) were male. The mean age of the sample was 16.2 (standard deviation 1.22) years.

Among all participants, 1047 (17.0\%) reported ever smoking any form of tobacco, with the majority smoking cigarettes 505 (8.9\%) followed by shisha 421 (7.4\%), 380 $(6.4 \%)$ other forms of tobacco, and 355 (6.3\%) midwakh. Four hundred and forty (8.2\%) reported using $>1$ form of tobacco, and 818 (14\%) were current smokers. For every age group and tobacco form, the prevalence of tobacco use was higher among men than women (Figure 1). For every age group, cigarette smoking was more popular among men: < 14 years: 6 (5.5\%); 15 years: 77 (12.4\%); 16 years: 99 (14.3\%); 17 years: 139 (19.8\%); 18 years: 40 (19.3\%); > 19 years: 30 (25.4\%). The highest proportion of male current smokers was in the age group > 19 years: 57 (44.2\%). In contrast, shisha was the most smoked form of tobacco among women in most age groups: < 14 years: 6 (3.1\%); 15 years: 20 (2.3\%); 17 years: 24 (3.4\%); 18 years: 5 (2.9\%), except in the 16 and > 19 years age groups, in which cigarettes were the most smoked form of tobacco: 32 (3.5\%) and 3 (3.8\%), respectively. The highest proportion of female current smokers was in the age group 18 years: 15 (7.4\%).

Results showed that $5.5 \%$ of women and $24 \%$ of men were current smokers (Table 1). There were significant differences in the proportions of current smokers and nonsmokers in relation to sex, age, type of school attended, exposure to tobacco at home or with friends, nationality, parental marital status, location of residence, residential crowding, and illegal drug use. Overall, the highest prevalence of current smoking was in the age groups 15-17 years for women and 16-17 years for men. Smoking prevalence was higher for men who attended public schools $(59.8 \%)$ compared to private schools (40.2\%), whereas the opposite trend was seen for women (34.5 vs $65.5 \%$ ). For nationality, the highest proportion of male smokers was from the UAE (246; 42\%). The highest proportion of female smokers was from Arab/Middle East group $(60 ; 35.1 \%)$. Compared to their respective counterparts, the highest prevalence of current smoking was among those who reported parental marital status of other, those who resided in Ajman, those who were not exposed to residential crowding, and those who reported ever using illegal drugs.

Significant differences in all forms of tobacco use were found in relation to sex, age, exposure to tobacco smoke at home or with friends, and illegal drug use (Table 2). The patterns of significant differences observed for each form of tobacco use in relation to the remaining explanatory variables varied.

Multivariate logistic regression modelling revealed that male sex and ever using illegal drugs were significant predictors of all forms of tobacco use (Table 3). For current smoking, attending private school, nationality and location of residence also emerged as significant predictors. In addition, predictors of cigarette smoking included increasing age, daily or occasional exposure to tobacco at home or with friends, GCC or Arab/Middle Eastern or Arab/African nationality, parental marital status identified as other, and location of residence. Predictors of midwakh smoking also included daily or occasional exposure to tobacco at home or with friends, while those of shisha smoking included increasing age, daily or occasional exposure to tobacco at home or with friends, and Arab/Middle Eastern or western nationality. For other forms of tobacco smoking, predictors included age, attending public school, daily or occasional exposure to tobacco at home or with friends, parental marital status identified as other, and residential mobility (4 previous residences). In relation to smoking $>1$ form of tobacco, significant predictors were male sex, increasing age, daily or occasional exposure to tobacco at home or with friends, Arab/Middle Eastern Arab/African or western nationality, parental marital status identified as other, location of residence, and ever using illegal drugs.

\section{Discussion}

In this study, 1047 (17\%) participants indicated that they had ever smoked cigarettes or any form of tobacco, while 818 (14\%) were current smokers. The GYTS 2013, administered to adolescents aged 13-15 years, reported higher prevalence rates for ever smoking (29.7\%) and lower prevalence rates for current smoking (10.5\%) (15). Although this difference suggests a possible decrease in current tobacco use, the prevalence of this health risk behaviour remains high and indicates the need for continuous efforts to discourage UAE adolescents from using tobacco $(15,16)$.

The prevalence of current smoking among men in the present study $(24 \%)$ was higher than that reported in GYTS 2013 (14.6\%) (15). In contrast, the prevalence of current smoking among women in the present study (5.5\%) was lower than that reported in GYTS 2013 (6.4\%), indicating that tobacco use is gaining popularity among women (15). While the GYTS 2013 focused on adolescents aged 13-15 years, our study included participants from a larger age range and found that the highest prevalence of current smoking was among men aged 19 years (44.2\%) and women aged 18 years (7.4\%). Furthermore, our findings point to a positive association between age and smoking cigarettes, $>1$ form of tobacco and shisha. A recent study among school students aged 10-20 years in Dubai reported prevalence rates of 11.2 and $2.2 \%$ for smoking cigarettes and shisha, respectively (10). This suggests higher prevalence rates of cigarette smoking and lower prevalence rates of shisha smoking compared to our study ( $8.8 \%$ and $6.2 \%$, respectively). These differences are likely to become more pronounced with the recent enactment of the Federal Anti-Tobacco law in early 2013 (16), which specifies that shisha may not be served to individuals aged $<18$ years.

Recently, several studies have highlighted an alarming increase in the use of unconventional forms of tobacco, including shisha and midwakh, particularly in the Gulf Region (17). Earlier reports from the GYTS suggest that the average rate of shisha smoking among 
(A) $\leq 14$ years

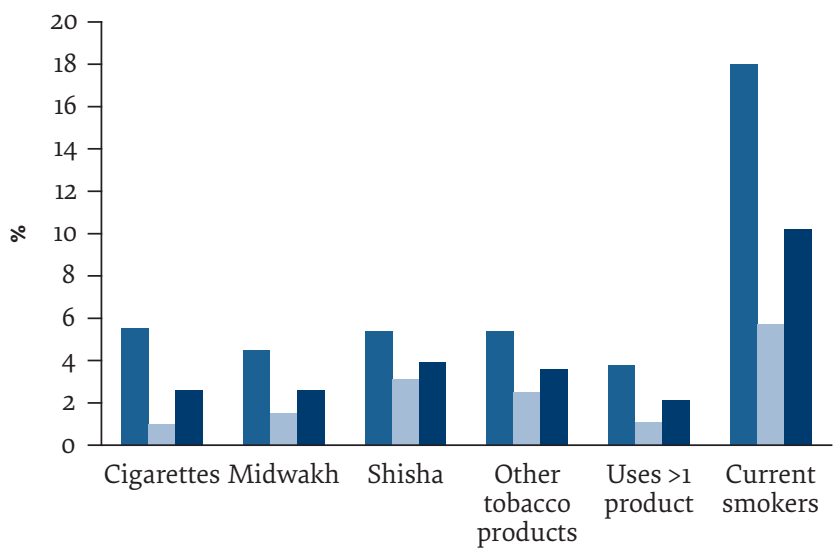

Tobacco forms

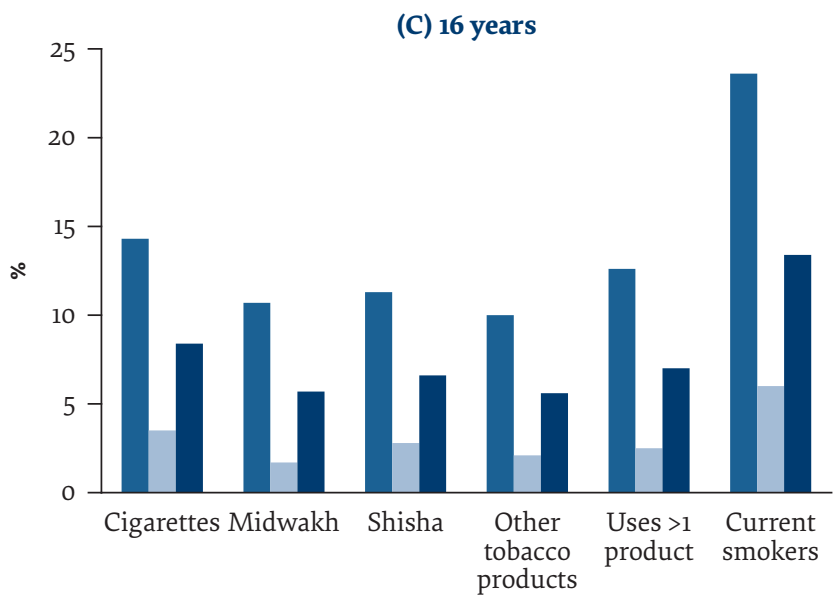

Tobacco forms

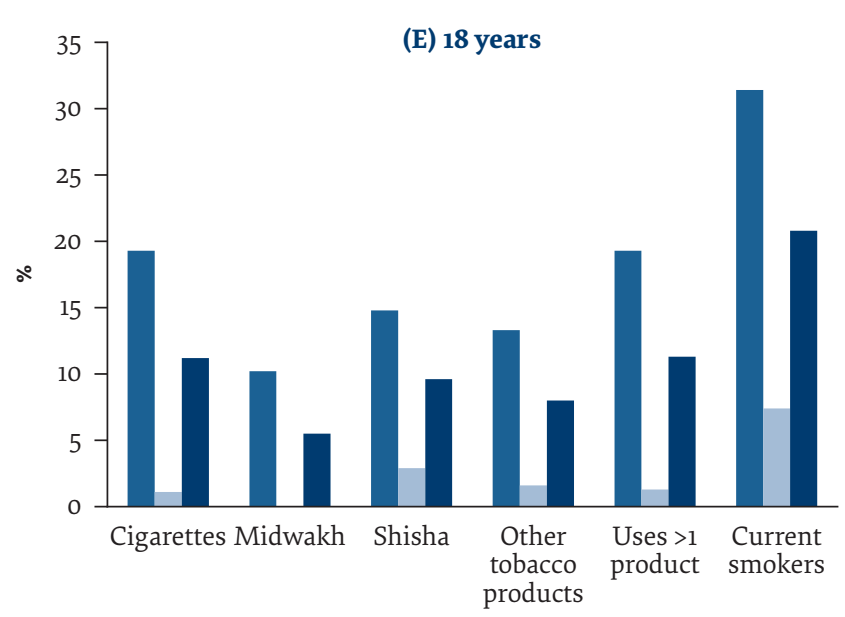

Tobacco forms
(B) 15 years

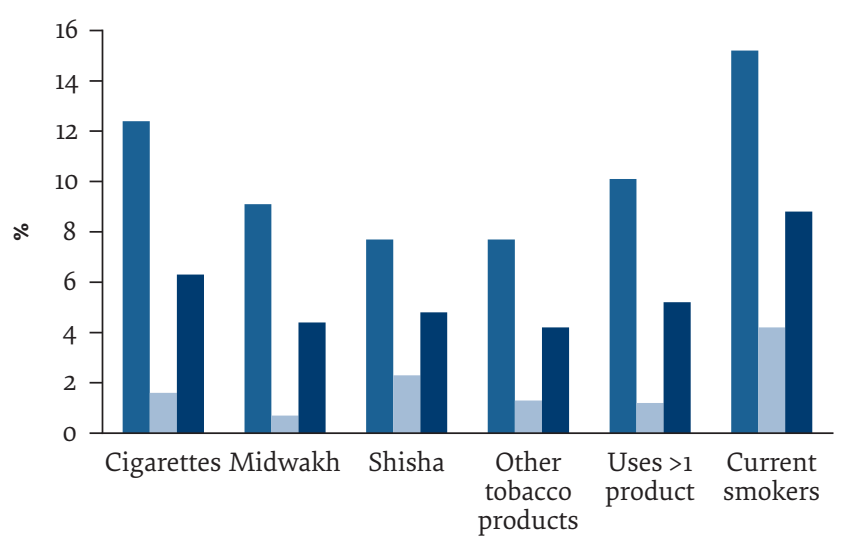

Tobacco forms

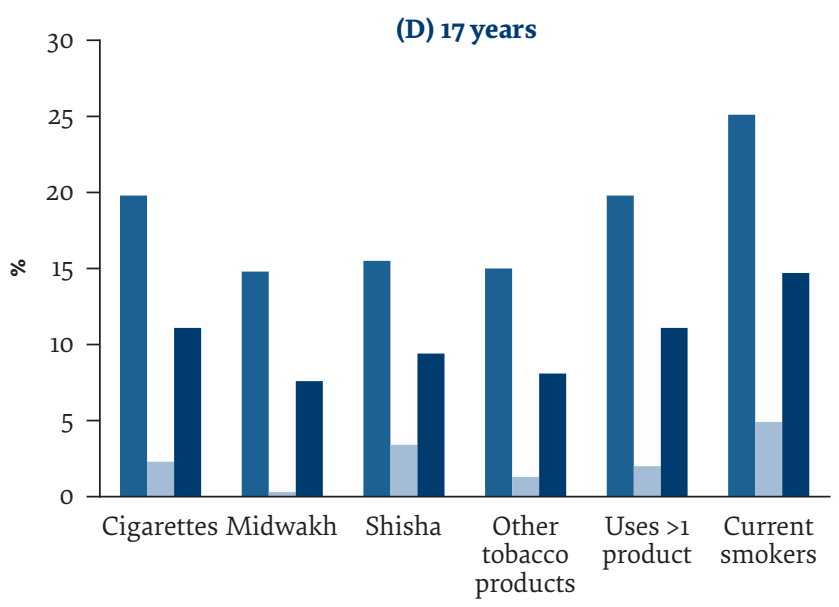

Tobacco forms

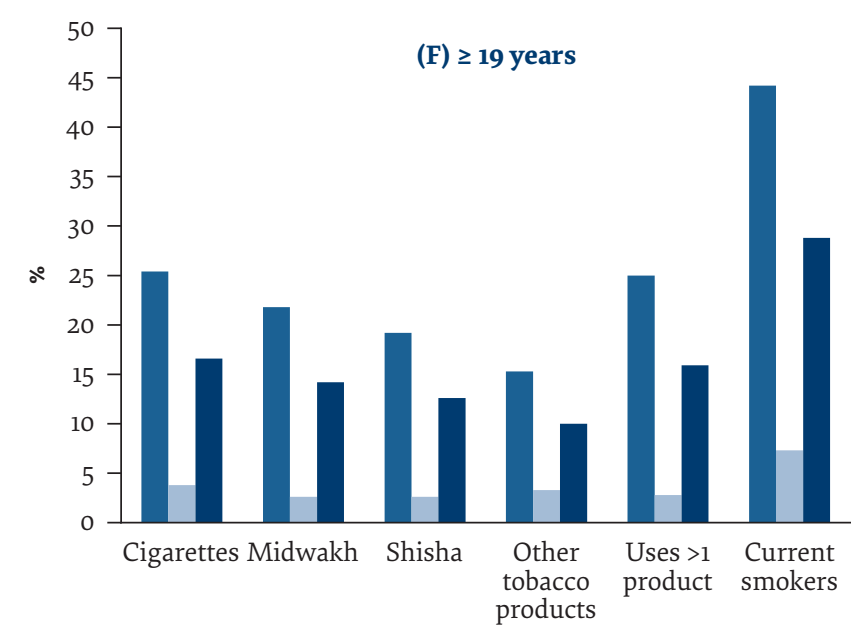

Tobacco forms

Male Female $\square$ Total

Figure 1 Distribution of tobacco use (\%) in relation to age and gender, among adolescents who reside in the United Arab Emirates ( $n=6363)$ 


\begin{tabular}{|c|c|c|c|c|}
\hline \multirow[b]{2}{*}{ Variable } & \multicolumn{4}{|c|}{ Prevalence of current smoking for: } \\
\hline & Classification & Overall, $\mathbf{n}(\%)$ & Male, $n$ (\%) & Female, $\boldsymbol{n}(\%)$ \\
\hline \multicolumn{2}{|l|}{ Current smoking } & $818(14.0)$ & $624(100)$ & $174(100)$ \\
\hline \multirow[t]{3}{*}{ Sex, $\mathrm{n}=798$} & & $* * *$ & & \\
\hline & Female & $174(5.5)$ & & \\
\hline & Male & $624(24.0)$ & & \\
\hline \multirow[t]{7}{*}{ Age, $y r, \mathrm{n}=746$} & & $* * *$ & & \\
\hline & $\leq 14$ & $31(10.2)$ & $20(3.5)$ & $11(6.8)$ \\
\hline & 15 & $137(8.8)$ & $98(17)$ & $38(23.5)$ \\
\hline & 16 & $221(13.4)$ & $161(28)$ & $57(35.2)$ \\
\hline & 17 & $219(14.7)$ & $181(31.4)$ & $37(22.8)$ \\
\hline & 18 & $81(20.8)$ & 66 (11.5) & $13(8)$ \\
\hline & $\geq 19$ & $57(28.8)$ & $50(8.7)$ & $6(3.7)$ \\
\hline \multirow[t]{3}{*}{ School, $\mathrm{n}=818$} & & ** & & \\
\hline & Public & $445(12.8)$ & $373(59.8)$ & $60(34.5)$ \\
\hline & Private & $373(15.9)$ & $251(40.2)$ & $114(65.5)$ \\
\hline \multirow{4}{*}{$\begin{array}{l}\text { Exposed to tobacco smoke at home or } \\
\text { with friends, } \mathrm{n}=698\end{array}$} & & $* * *$ & & \\
\hline & Not at all & $272(8.8)$ & $198(36.8)$ & $69(47.3)$ \\
\hline & Occasionally & $237(17.5)$ & $189(35.1)$ & $44(30.1)$ \\
\hline & Daily & $189(30.0)$ & $44(30.1)$ & $33(22.6)$ \\
\hline \multirow[t]{2}{*}{ UAE born, $\mathrm{n}=789$} & No & $209(14.6)$ & $138(22.7)$ & $69(40.8)$ \\
\hline & Yes & $580(13.6)$ & $471(77 \cdot 3)$ & $100(59.2)$ \\
\hline \multirow[t]{8}{*}{ Ethnicity, $\mathrm{n}=\mathbf{7 9 2}^{a}$} & & $* * *$ & & \\
\hline & UAE & $318(11.3)$ & $256(42)$ & 54 (31.6) \\
\hline & GCC & $61(19.2)$ & $54(8.9)$ & $6(3.5)$ \\
\hline & Arab/Middle East & $215(23.9)$ & $155(25.4)$ & $60(35.1)$ \\
\hline & Arab/Africa & $93(16.0)$ & $83(13.6)$ & $10(5.8)$ \\
\hline & South East Asia & $66(7.0)$ & $44(7.2)$ & $21(12.3)$ \\
\hline & Western & $22(27.5)$ & $6(1.0)$ & $15(8.8)$ \\
\hline & None/other & $17(23.0)$ & $12(2.0)$ & $5(2.9)$ \\
\hline \multirow[t]{5}{*}{ Parental marital status, $n=783$} & & ** & & \\
\hline & Married & $687(13.8)$ & $535(88.1)$ & $150(86.7)$ \\
\hline & Widowed & $27(12.4)$ & $41(6.8)$ & $7(4.0)$ \\
\hline & Separated/divorced & $22(9.8)$ & $11(1.8)$ & $7(4.0)$ \\
\hline & Other & $47(20.2)$ & $20(3.3)$ & $9(5.2)$ \\
\hline \multirow{2}{*}{$\begin{array}{l}\text { Father graduated from high school, } \\
\mathrm{n}=605\end{array}$} & No & $243(12.5)$ & $195(42.1)$ & $40(30.5)$ \\
\hline & Yes & $362(13.3)$ & $268(57.9)$ & $91(69.5)$ \\
\hline \multirow{2}{*}{$\begin{array}{l}\text { Mother graduated from high school, } \\
\mathrm{n}=597\end{array}$} & No & $291(12.4)$ & $235(51.6)$ & $50(37.9)$ \\
\hline & Yes & $306(13.1)$ & $220(48.4)$ & $82(62.1)$ \\
\hline \multirow{8}{*}{$\begin{array}{l}\text { Monthly household income (AED), } \\
\mathrm{n}=479\end{array}$} & $\leq 2 \mathrm{~K}$ & $17(11.8)$ & $13(3.4)$ & $3(3.2)$ \\
\hline & $>2$ and $\leq 5 \mathrm{~K}$ & $100(12.1)$ & $88(23.3)$ & $12(12.8)$ \\
\hline & $>5$ and $\leq 8 \mathrm{~K}$ & $81(12.8)$ & $63(16.7)$ & $15(16.0)$ \\
\hline & $>8$ and $\leq 10 \mathrm{~K}$ & $52(12.0)$ & $41(10.8)$ & $10(10.6)$ \\
\hline & $>10$ and $\leq 12 \mathrm{~K}$ & $42(13.0)$ & $34(9.0)$ & $8(8.5)$ \\
\hline & $>12$ and $\leq 15 \mathrm{~K}$ & $44(15.0)$ & $33(8.7)$ & $10(10.6)$ \\
\hline & $>15$ and $\leq 20 \mathrm{~K}$ & $38(14.6)$ & $29(7.7)$ & $9(9.6)$ \\
\hline & $>20 \mathrm{~K}$ & $105(16.1)$ & $77(20.4)$ & $27(28.7)$ \\
\hline \multirow[t]{2}{*}{ Income divided (AED), $\mathrm{n}=469^{b}$} & $<15 \mathrm{~K}$ & $342(12.9)$ & $272(74.3)$ & $63(65.6)$ \\
\hline & $\geq 15 \mathrm{~K}$ & $127(13.9)$ & $94(25.7)$ & $33(34.4)$ \\
\hline \multirow[t]{8}{*}{ Location of residence, $\mathrm{n}=818$} & & $* * *$ & & \\
\hline & Abu Dhabi & $411(15.0)$ & $331(53.0)$ & $71(40.8)$ \\
\hline & Ajman & $39(17.9)$ & $23(3.7)$ & $16(9.2)$ \\
\hline & Dubai & $75(13.9)$ & $64(10.3)$ & $11(6.3)$ \\
\hline & Fujairah & $62(12.8)$ & $37(5.9)$ & $22(12.6)$ \\
\hline & RAK & $51(8.3)$ & $38(6.1)$ & $10(5.7)$ \\
\hline & Sharjah & $170(15.5)$ & $125(20.0)$ & $41(23.6)$ \\
\hline & UAQ & $10(7.6)$ & $6(1.0)$ & $3(1.7)$ \\
\hline \multirow{3}{*}{$\begin{array}{l}\text { Residential } \\
\text { Crowding, } \mathrm{n}=234^{c}\end{array}$} & & * & & \\
\hline & No & $106(8.7)$ & $74(44.0)$ & $30(47.6)$ \\
\hline & Yes & $128(6.7)$ & $94(56.0)$ & $33(52.4)$ \\
\hline
\end{tabular}


Table 1 Demographic, socioeconomic, residential and behavioural profiles of study participants $(n=6363)$ (concluded)

\begin{tabular}{|c|c|c|c|c|}
\hline \multirow[b]{2}{*}{ Variable } & \multicolumn{4}{|c|}{ Prevalence of current smoking for: } \\
\hline & Classification & Overall, $\boldsymbol{n}(\%)$ & Male, $\boldsymbol{n}(\%)$ & Female, $\boldsymbol{n}(\%)$ \\
\hline \multirow{5}{*}{$\begin{array}{l}\text { Number of previous residences, } \\
\mathrm{n}=818\end{array}$} & None & $580(14.5)$ & 444 (71.2) & $117(67.2)$ \\
\hline & 1 & $160(13.5)$ & $120(19.2)$ & $40(23.0)$ \\
\hline & 2 & $41(12.1)$ & $30(4.8)$ & $10(5.7)$ \\
\hline & 3 & $18(11.3)$ & $16(2.6)$ & $2(1.1)$ \\
\hline & 4 & $19(13.8)$ & $14(2.2)$ & $5(2.9)$ \\
\hline \multirow[t]{3}{*}{ Ever used illegal drugs, $\mathbf{n}=800$} & & $* * *$ & & \\
\hline & No & $757(13.8)$ & $584(94.8)$ & $159(95.8)$ \\
\hline & Yes & $43(47.8)$ & $32(5.2)$ & $7(4.2)$ \\
\hline \multirow[t]{2}{*}{ Unconventional drug use, $\mathrm{n}=795$} & No & $577(14.8)$ & $476(77.8)$ & $91(54.8)$ \\
\hline & Yes & $218(13.2)$ & $136(22.2)$ & $75(45.2)$ \\
\hline
\end{tabular}

${ }^{*} \mathrm{P}<0.05 ;{ }^{* *} \mathrm{P}<0.01 ;{ }^{* * *} \mathrm{P}<0.001$.

aUAE = local; GCC = Kuwait, Saudi Arabia, Oman, Qatar, Bahrain and Yemen; Arab/Middle East = Lebanon, Syria, Jordan, Palestine and Iraq; Arab/Africa = Egypt, Tunisia, Morocco, Algeria, Libya, Sudan and Somalia; South East Asia = India, Pakistan, Bangladesh, Sri Lanka, Philippines and Indonesia; Western = Europe, United States of America, Australia, Canada; No nationality and Others = all other nationalities.

aCutoff based on data from the UAE Ministry of Economy, indicating that the average monthly income for Emirati households is AED 36438.10 and that for expatriate households is AED 15 074.30 .

$b$ Calculated using the ratio for the number of individuals that reside in the household over the number of bedrooms in the house. $A E D=$ United Arab Emirates dirham; $R A K=$ Ras al-Khaimah; $U A Q=$ Umm al-Quwain .

\begin{tabular}{|c|c|c|c|c|c|c|}
\hline \multirow[t]{2}{*}{ Variable } & \multirow[t]{2}{*}{ Classification } & $\begin{array}{l}\text { Cigarettes } \\
(n=505)\end{array}$ & $\begin{array}{l}\text { Midwakh } \\
(n=355)\end{array}$ & $\begin{array}{l}\text { Shisha } \\
(n=421)\end{array}$ & $\begin{array}{l}\text { Other } \\
(n=380)\end{array}$ & $\begin{array}{c}\text { Uses }>1 \text { tobacco } \\
\text { form } \\
(n=440)\end{array}$ \\
\hline & & $n(\%)$ & n (\%) & $n(\%)$ & $n(\%)$ & $n(\%)$ \\
\hline \multirow[t]{3}{*}{ Sex } & & $* * *$ & $* * *$ & $* * *$ & $* * *$ & $* * *$ \\
\hline & Female & $71(2.4)$ & $29(1.0)$ & $84(2.8)$ & $57(1.8)$ & $52(1.8)$ \\
\hline & Male & $416(16.2)$ & $310(12.1)$ & $320(12.4)$ & $303(11.4)$ & $371(15.1)$ \\
\hline \multirow[t]{7}{*}{ Age,yr } & & $* * *$ & $* * *$ & $* * *$ & $* * *$ & $* * *$ \\
\hline & $\leq 14$ & $8(2.6)$ & $8(2.6)$ & $12(3.9)$ & $11(3.6)$ & $6(2.1)$ \\
\hline & 15 & $94(6.3)$ & $66(4.4)$ & $72(4.8)$ & $67(4.2)$ & $74(5.2)$ \\
\hline & 16 & $135(8.4)$ & $92(5.7)$ & $106(6.6)$ & $94(5.6)$ & $108(7.0)$ \\
\hline & 17 & $158(11.1)$ & $109(7.6)$ & $134(9.4)$ & $122(8.1)$ & $148(7.0)$ \\
\hline & 18 & $43(11.2)$ & $21(5.5)$ & $37(9.6)$ & $32(8.0)$ & 40 (11.3) \\
\hline & $\geq 19$ & $33(16.6)$ & $28(14.2)$ & $25(12.6)$ & $21(10.0)$ & $29(15.9)$ \\
\hline \multirow[t]{3}{*}{ School } & & & $* *$ & $* * *$ & $* *$ & * \\
\hline & Public & $303(9.2)$ & $235(7.1)$ & $211(6.4)$ & $253(7.1)$ & $274(8.9)$ \\
\hline & Private & $202(8.5)$ & $120(5.1)$ & $210(8.9)$ & $127(5.3)$ & $166(7.3)$ \\
\hline \multirow{4}{*}{$\begin{array}{l}\text { Exposed to tobacco } \\
\text { smoke at home or } \\
\text { with friends }\end{array}$} & & $* * *$ & $* * *$ & $* * *$ & $* * *$ & $* * *$ \\
\hline & Not at all & $92(3.0)$ & $52(1.7)$ & $84(2.8)$ & $68(2.1)$ & $60(2.0)$ \\
\hline & Occasionally & $159(12.3)$ & $108(8.3)$ & $134(10.3)$ & $116(8.3)$ & $150(12.2)$ \\
\hline & Daily & $176(29.4)$ & $133(22.1)$ & 139 (23.0) & $124(19.3)$ & $183(28.7)$ \\
\hline \multirow[t]{3}{*}{ UAE born } & & & $* *$ & & & * \\
\hline & No & $114(8.0)$ & $61(4.3)$ & $119(8.4)$ & $80(5.4)$ & $92(6.7)$ \\
\hline & Yes & $372(9.0)$ & $278(6.7)$ & $284(6.9)$ & $284(6.5)$ & $331(8.6)$ \\
\hline \multirow[t]{8}{*}{ Ethnicity $^{a}$} & & $* * *$ & & $* * *$ & & $* * *$ \\
\hline & UAE & 187 (6.9) & $155(5.7)$ & $121(4.5)$ & $173(6.1)$ & $170(6.7)$ \\
\hline & GCC & $43(13.6)$ & $30(9.5)$ & $22(6.9)$ & $31(9.1)$ & 35 (11.6) \\
\hline & Arab/Middle East & 137 (16.0) & $84(9.9)$ & $165(19.3)$ & $75(8.1)$ & $128(15.9)$ \\
\hline & Arab/Africa & $70(12.7)$ & $41(7.4)$ & $42(7.7)$ & $49(8.3)$ & $51(9.7)$ \\
\hline & South East Asia & $33(3.4)$ & $19(2.0)$ & $29(3.0)$ & $22(2.3)$ & $20(2.1)$ \\
\hline & Western & $10(12.3)$ & $6(7.5)$ & $17(21.0)$ & $7(8.8)$ & $11(13.9)$ \\
\hline & None/other & $7(10.0)$ & $4(5.7)$ & $9(13.0)$ & $4(5.1)$ & $6(9.0)$ \\
\hline \multirow{5}{*}{$\begin{array}{l}\text { Parental marital } \\
\text { status }\end{array}$} & & $*$ & $* * *$ & & $* * *$ & $* *$ \\
\hline & Married & $409(8.4)$ & $282(5.8)$ & $346(7.2)$ & $290(5.7)$ & $351(7.7)$ \\
\hline & Widowed & $16(7.5)$ & $10(4.7)$ & $13(6.2)$ & $15(6.9)$ & $13(6.6)$ \\
\hline & Separated/ & $19(8.7)$ & $12(5.5)$ & $13(5.9)$ & $18(7.8)$ & $18(8.6)$ \\
\hline & $\begin{array}{l}\text { Divorced } \\
\text { Other }\end{array}$ & $33(14.8)$ & $28(12.6)$ & $23(10.3)$ & $32(14.0)$ & $31(14.8)$ \\
\hline \multirow{3}{*}{$\begin{array}{l}\text { Father graduated } \\
\text { from high school }\end{array}$} & & & * & * & & \\
\hline & No & $159(8.5)$ & $120(6.4)$ & $102(5.5)$ & $122(6.1)$ & $135(7.7)$ \\
\hline & Yes & $197(7.4)$ & $130(4.9)$ & $195(7.3)$ & 159 (5.7) & $174(6.9)$ \\
\hline
\end{tabular}




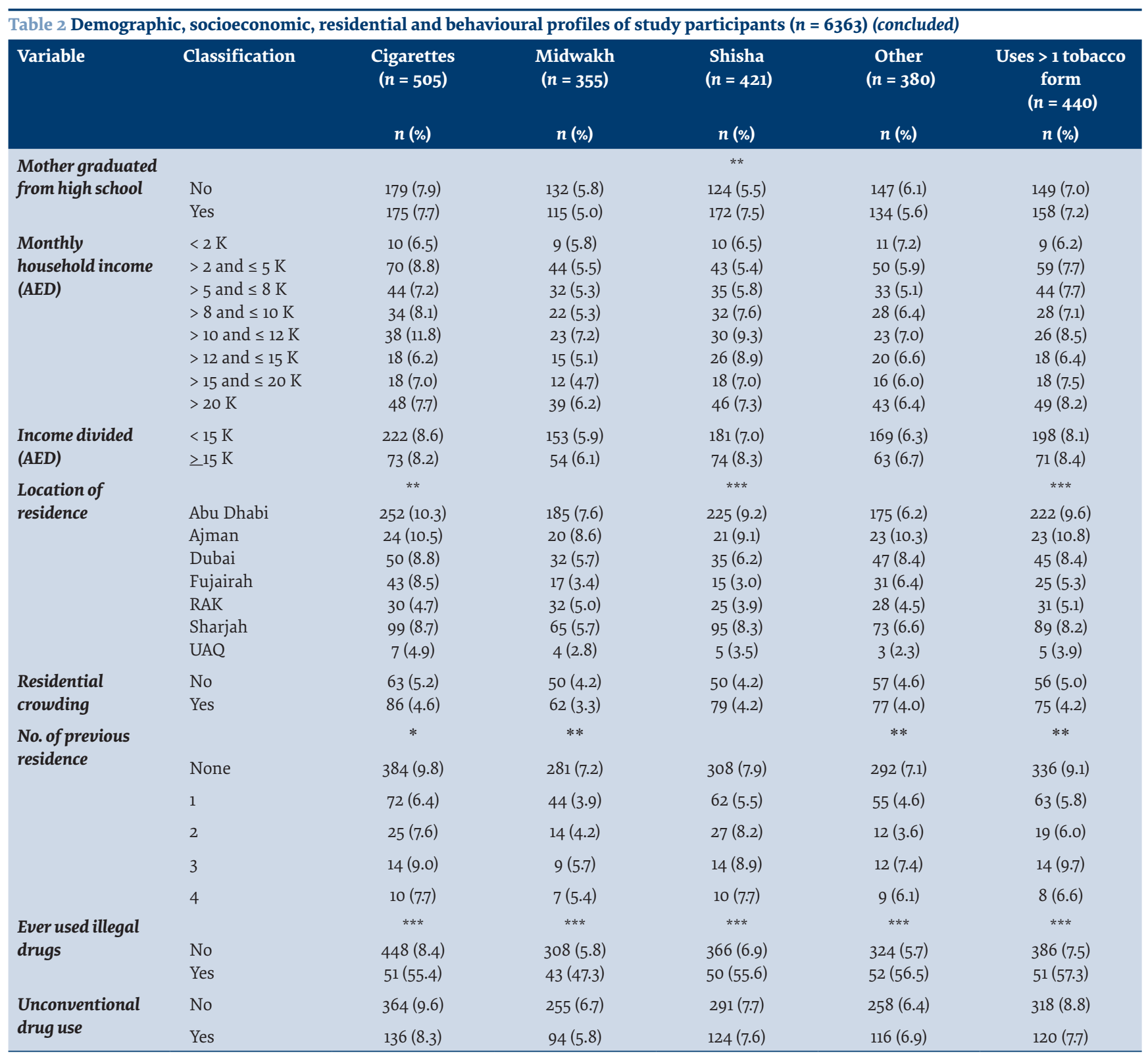

${ }^{*} \mathrm{P}<0.05 ;{ }^{* *} \mathrm{P}<0.01 ;{ }^{* * *} \mathrm{P}<0.001$

$a U A E=$ local; GCC = Kuwait, Saudi Arabia, Oman, Qatar, Bahrain and Yemen; Arab/Middle East = Lebanon, Syria, Jordan, Palestine and Iraq; Arab/Africa = Egypt, Tunisia, Morocco, Algeria, Libya, Sudan and Somalia; South East Asia = India, Pakistan, Bangladesh, Sri Lanka, Philippines and Indonesia; Western = Europe, United States of America, Australia, Canada; No nationality and None/other $=$ all other nationalities.

$A E D=$ United Arab Emirates dirham; RAK = Ras al-Khaimah; UAQ = Umm al-Quwain. 


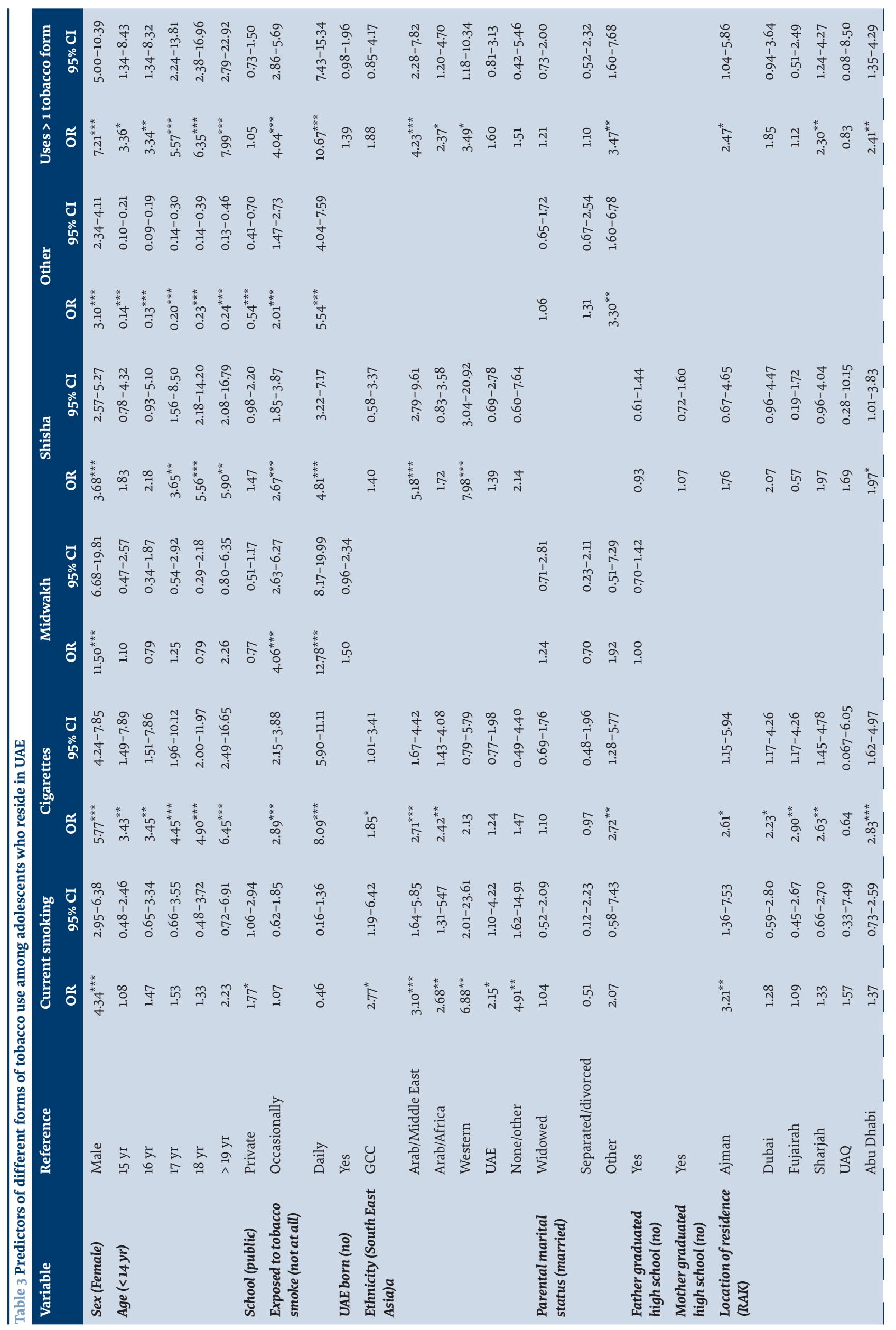




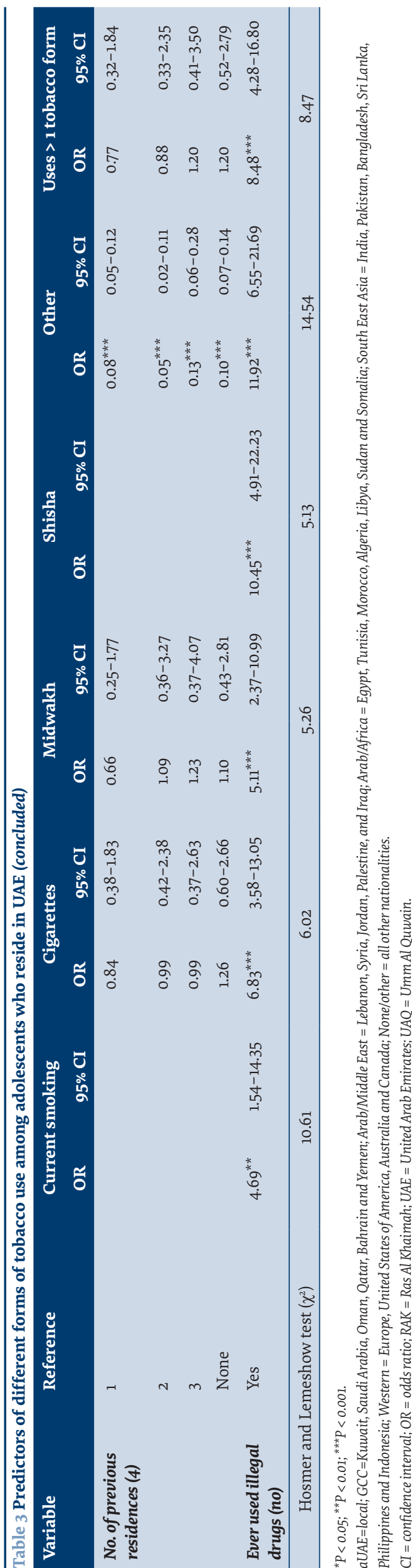

adolescents aged 13-15 years has increased from $15 \%$ in 2002 to $28.2 \%$ in 2005 . The GYTS findings raise concerns over shisha use by a group of students who have never smoked (18). The overall prevalence of shisha smoking in our sample is comparable to the prevalence of cigarette smoking across all age groups. This highlights the need for continued public health strategies and education campaigns to discourage adolescents from smoking other forms of tobacco, specifically shisha.

We found that the prevalence of midwakh smoking was $7.6,5.5$ and $14.2 \%$ for the 17,18 and $>19$ years age groups, respectively. According to Al-Houqani, midwakh accounted for $15 \%$ of all tobacco smokers in Abu Dhabi, with a young age of onset (5). An alarming prevalence of midwakh smoking among medical students has been reported in Ajman, with 30 and 5\% prevalence among male and female students, respectively (9). A more recent study conducted in 2015 for the same age group in Ajman reported a dramatic increase in the prevalence rate of midwakh smoking (36\% had ever smoked and $29 \%$ currently smoked) (19). Similar to our results, prevalence rates increased with age. This increase in the use of other forms of tobacco could be due to the widespread misconception that these forms are less harmful than cigarettes.

Our study suggests that cigarettes are the most common form of tobacco among men, while shisha is the most common among women. This observed difference in smoking behaviour is not surprising given the social context in the UAE, where social norms may be more accepting of men smoking cigarettes. This may urge women to under-report their cigarette smoking habits, and report their shisha smoking given that the latter may be more socially accepted (20). Anti-tobacco education campaigns should address this social context, thus emphasizing the health risks of all forms of tobacco to both male and female adolescents.

There are policies to prevent adolescents aged $<18$ years purchasing tobacco products in the UAE; however, those attending private school may be more likely to purchase these products than their counterparts. Our results also suggest that adolescents who attend private schools are more likely to be current smokers. Possible explanations focus on the issue of policy enforcement, as well as the ability for these adolescents to purchase tobacco products, as they are likely to have greater material resources compared to those who attend public schools. Moreover, it could be related to the demographic composition in UAE public schools, where the majority of students are expatriates, and that tobacco smoking may be more prevalent among expatriate adolescents compared to nationals.

There is a well-established link between parental smoking and adolescent initiation of smoking, regular smoking, and persistence of smoking into adulthood (21). Many prospective studies have also demonstrated positive associations between peer and adolescent tobacco use (22). Similarly, our results suggest that adolescents who are exposed to tobacco smoke at home 
or with friends are more likely to smoke. This highlights the importance of supporting anti-tobacco education campaigns and interventions that aim to alter social norms in peer/family settings $(21,22)$.

Our findings suggest that nationality is linked to tobacco smoking, which is consistent with previous findings $(2,23)$. Adolescents from western countries are more likely to smoke shisha and use $>1$ form of tobacco than adolescents from South East Asia. This may be because shisha smoking is gaining steady popularity among adolescents in western countries (24). Western adolescents who reside in the UAE also may be influenced by the social acceptance of smoking and feel inclined to smoke a variety of tobacco forms that are available in this country.

Our results indicate that location of residence is linked to tobacco use. This can be explained by the demographic and social differences among the different emirates. In particular, residents in Ras Al Khaimah have fewer opportunities for shisha bars and social gatherings. Furthermore, there was a lower representation of men from Umm al Quwain in this study, which is likely linked to the lower prevalence of smoking.

Our results show that adolescents who report ever using illegal drugs are more likely to engage in all types of tobacco use. It may be useful to incorporate tobaccouse prevention strategies in drug abuse treatment programmes (25). Although the prevalence of illegal drug use is low in the UAE compared to international standards, it is imperative that public health programmes continue to focus on strengthening their current educational campaigns to prevent adolescents from using illegal drugs (26).

The present study had several limitations. Data were self-reported and may have been subject to response bias. Sampling led to lower representations of adolescents who attended private schools in Dubai and among men who resided in Umm al Quwain. This is relevant as the population of Dubai consists of a large proportion of expatriates. Response to the survey may have been influenced by the presence of social workers, with the possibility of under-reporting tobacco use among women, given social norms, as well as under-reporting of illegal drug use among all participants. Despite these limitations, our findings present a detailed profile of tobacco use among UAE adolescents that is crucial for reducing the prevalence of tobacco use among adolescents and tobacco-related diseases.

\section{Acknowledgements}

This work was supported by a Zayed University Research Incentive Fund. We acknowledge Zayed University and the UAE Ministry of Education for their contribution in the initial phase of this research.

Funding: None.

Conflict of interest: None.

\section{Facteurs prédictifs sociodémographiques du tabagisme parmi les adolescents expatriés et nationaux aux Émirats arabes unis}

\section{Résumé}

Contexte: Les recherches récentes permettent de dégager des estimations qui montrent que plus de 150 millions d'adolescents consomment du tabac dans le monde. Le tabagisme chez l'adolescent est une importante préoccupation de santé publique du fait des risques pour la santé liés au fait de fumer. Par ailleurs, il peut mener à d'autres formes d'abus de substances psychoactives.

Objectif : La présente étude examinait la prévalence, le profil et les facteurs prédictifs de la consommation de tabac chez les adolescents expatriés et nationaux aux Émirats arabes unis.

Méthodes : À l'aide d'un plan d'étude transversale (2007-2009), nous avons collecté des données sur la prévalence du tabagisme chez 6363 adolescents âgés de 13 à 20 ans, comprenant des fumeurs de cigarettes, de midwakh, de shisha et de toute autre forme de tabac au moment de l'enquête. Nous avons par ailleurs recueilli des données démographiques, socioéconomiques, résidentielles et comportementales.

Résultats : Durant les 30 jours précédents, $505(8,9 \%)$ des participants avaient fumé des cigarettes, $355(6,3 \%)$ avaient fumé la midwakh, $421(7,4 \%)$ avaient fumé la shisha et $380(6,4 \%)$ avaient consommé toute autre forme de tabac. Globalement, $14,0 \%$ des adolescents étaient des fumeurs au moment de l'étude, notifiant l'utilisation occasionnelle ou quotidienne d'au moins une forme de tabac au cours des 30 derniers jours. Les résultats ont généralement indiqué que la prévalence de la consommation de tabac était plus forte chez les hommes que chez les femmes, indépendamment de l'âge et de la forme de tabac consommée. Chez les hommes, la consommation de cigarettes était la plus populaire, tandis que la shisha était la forme de tabac la plus utilisée chez les femmes. Le fait d'être un homme et d'avoir déjà consommé des drogues illégales ressortait généralement comme facteur prédictif significatif de toutes formes de consommation de tabac.

Conclusion: Des stratégies de santé publique et des campagnes d'éducation permanentes sont nécessaires pour décourager les adolescents de consommer du tabac au Émirats arabes unis. 
المنبئات الاجتحاعية-السكانية لتدخين التبغ في صفوف اليافعين المغتربين والمو اطنين في دولة الإمارات العربية المتحدة

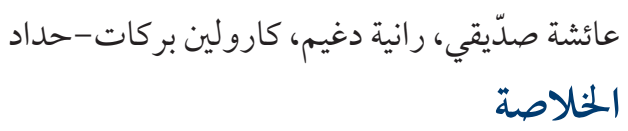

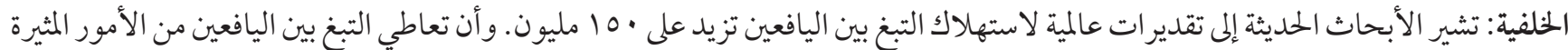

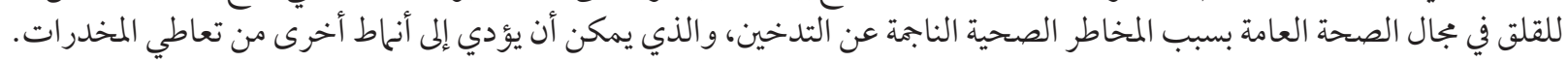

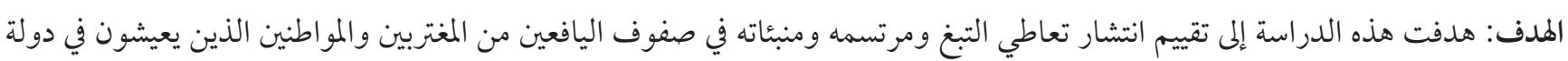

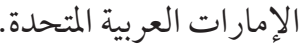

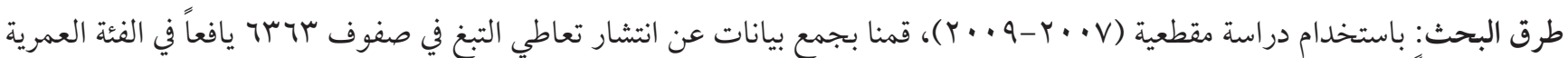

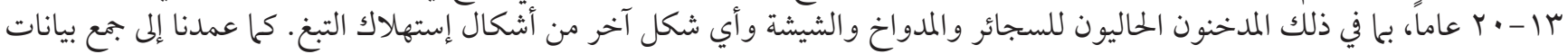

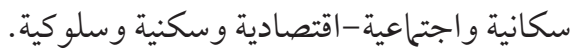

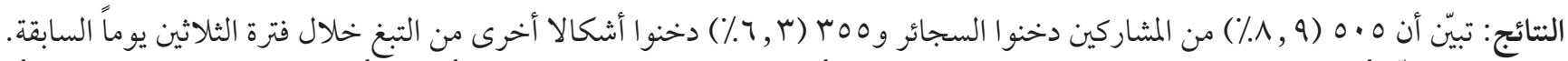

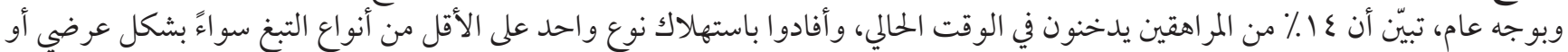

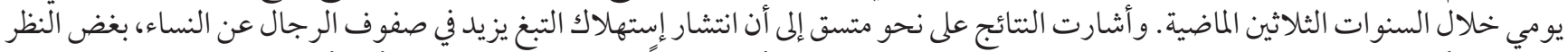

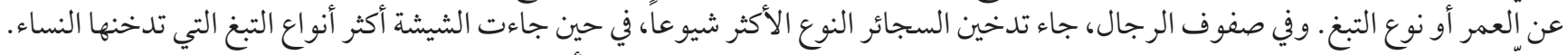

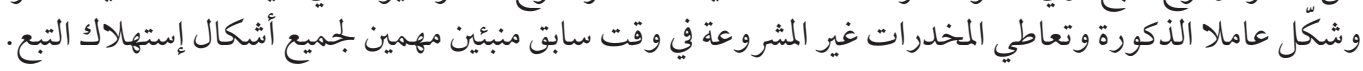

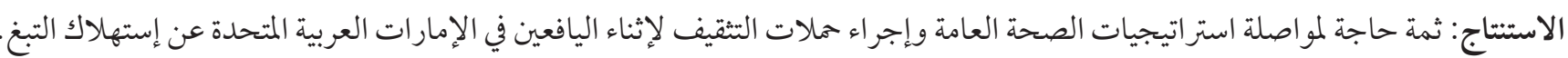

\section{References}

1. Hajeri AA. Tobacco use in adolescents. Bahrain Med Bull. 2010 Dec;32(4) (http://www.bahrainmedicalbulletin.com/ december_2010/Tobacco.pdf).

2. Park SH. Smoking and adolescent health. Korean J Pediatr. 2011 Oct;54(10):401-4. http://dx.doi.org/10.3345/kjp.2011.54.10.401 PMID:22232621

3. Caponnetto P, Polosa R. Common predictors of smoking cessation in clinical practice. Respir Med. 2008 Aug;102(8):1182-92. http://dx.doi.org/10.1016/j.rmed.2008.02.017 PMID:18586479

4. Hublet A, De Bacquer D, Valimaa R, Godeau E, Schmid H, Rahav G, et al. Smoking trends among adolescents from 1990 to 2002 in ten European countries and Canada. BMC Public Health. 200611 10;6(1):280. http://dx.doi.org/10.1186/1471-2458-6-280 PMID:17096837

5. Al-Houqani M, Ali R, Hajat C. Tobacco smoking using Midwakh is an emerging health problem-evidence from a large crosssectional survey in the United Arab Emirates. PLoS One. 2012;7(6):e39189. http://dx.doi.org/10.1371/journal.pone.0039189 PMID:22720071

6. Fikri M, Abi Saab BH. Global Youth Tobacco Survey (GYTS): United Arab Emirates report 2002. Abu Dhabi: United Arab Emirates Ministry of Health; 2002 (http://www.who.int/tobacco/surveillance/United\%20Arab\%20Emirates\%20Report\%202002.pdf, accessed 12 December).

7. Rai BS. MoH launches 3-year anti-smoking campaign. Emirates 24/7 News. 30 May 2013 (http://www.emirates247.com/news/ emirates/moh-launches-3-year-anti-smoking-campaign-2013-05-30-1.508584, accessed 12 December 2017).

8. Bener A, al-Ketbi LM. Cigarette smoking habits among high school boys in a developing country. J R Soc Promot Health. 1999 Sep;119(3):166-9. http://dx.doi.org/10.1177/146642409911900306 PMID:10518355

9. Jayakumary M, Jayadevan S, Ranade AV, Mathew E. Prevalence and pattern of dokha use among medical and allied health students in Ajman, United Arab Emirates. Asian Pac J Cancer Prev. 2010;11(6):1547-9. PMID:21338195

10. Obaid HA, Hassan MA, Mahdy NH, ElDisouky MI, Alzarba FE, Alnayeemi SR, et al. Tobacco use and associated factors among school students in Dubai, 2010: intervention study. East Mediterr Health J. 201502 2;20(12):765-73. PMID:25664514

11. Global Youth Tobacco Survey: country fact sheets. World Health Organization; 2010 (http://www.emro.who.int/images/stories/tfi/ documents/GYTS_FS_UAE_R2.pdf, accessed 12 December 2017).

12. Barakat-Haddad C. Prevalence of high blood pressure, heart disease, thalassemia, sickle-cell anemia, and iron-deficiency anemia among the UAE adolescent population. J Environ Public Health. 2013;2013:680631.

13. Guidelines for controlling and monitoring the tobacco epidemic. Geneva: World Health Organization; 1998.

14. Public Notification: "Black Ant" contains undeclared drug ingredient. Silver Spring, MD: U.S. Food and Drug Administration; 2011 (http://www.fda.gov/Safety/MedWatch/SafetyInformation/SafetyAlertsforHumanMedicalProducts/ucm247434.htm, accessed 12 December 2017). 
15. Global Youth Tobacco Survey: United Arab Emirates 2013 fact sheet. World Health Organization; 2013 (http://apps.who.int/fctc/ implementation/database/sites/implementation/files/documents/reports/uae_annex2_gyts_2013.pdf, accessed 12 December 2017).

16. UAE Anti-tobacco law in effect: rules and fines... Emirates 24/7 News 21 January 2014 (http://www.emirates247.com/news/ emirates/uae-anti-tobacco-law-in-effect-rules-and-fines-2014-01-21-1.535551, accessed12 December 2017).

17. Vupputuri S, Hajat C, Al-Houqani M, Osman O, Sreedharan J, Ali R et al. Midwakh/dokha tobacco use in the Middle East: much to learn. Tob Control. 2016 Mar;25(2):236-41. http://dx.doi.org/10.1136/tobaccocontrol-2013-051530 PMID:25342581

18. El-Awa F, Warren CW, Jones NR. Changes in tobacco use among 13-15-year-olds between 1999 and 2007: findings from the Eastern Mediterranean Region. East Mediterr Health J. 2010 Mar;16(3):266-73. PMID:20795439

19. Al Shemmari N, Shaikh RB, Sreedharan J. Prevalence of dokha use among secondary school students in Ajman, United Arab Emirates. Asian Pac J Cancer Prev. 2015;16(2):427-30. http://dx.doi.org/10.7314/APJCP.2015.16.2.427 PMID:25684466

20. El-Roueiheb Z, Tamim H, Kanj M, Jabbour S, Alayan I, Musharrafieh U. Cigarette and waterpipe smoking among Lebanese adolescents, a cross-sectional study, 2003-2004. Nicotine Tob Res. 2008 Feb;10(2):309-14. http://dx.doi. org/10.1080/14622200701825775 PMID:18236295

21. Turner L, Mermelstein R, Flay B. Individual and contextual influences on adolescent smoking. Ann N Y Acad Sci. 2004 Jun;1021(1):175-97. http://dx.doi.org/10.1196/annals.1308.023 PMID:15251888

22. Simons-Morton BG, Farhat T. Recent findings on peer group influences on adolescent smoking. J Prim Prev. 2010 Aug;31(4):191208. http://dx.doi.org/10.1007/s10935-010-0220-x PMID:20614184

23. Tobacco use: data by country. World Health Organization; 2009 (http://apps.who.int/gho/data/node.main.65, accessed 16 January 2018.

24. Akl EA, Gunukula SK, Aleem S, Obeid R, Jaoude PA, Honeine R, et al. The prevalence of waterpipe tobacco smoking among the general and specific populations: a systematic review. BMC Public Health. 2011 Apr 19;11(1):244. http://dx.doi.org/10.1186/14712458-11-244 PMID:21504559

25. Richter KP, Ahluwalia HK, Mosier MC, Nazir N, Ahluwalia JS. A population-based study of cigarette smoking among illicit drug users in the United States. Addiction. 2002 Jul;97(7):861-9. http://dx.doi.org/10.1046/j.1360-0443.2002.00162.x PMID:12133125

26. United Arab Emirates 2013 crime and safety report: Abu Dhabi: Overseas Security Advisory Council; 2013 (https://www.osac.gov/ Pages/ContentReportDetails.aspx?cid=13886, accessed12 December 2017). 